\title{
Misconceptions between Social Studies and Social Sciences among Pre- Service Elementary Teachers
}

\author{
Miftakhuddin $^{1}$, Ali Mustadi ${ }^{2}$, Heri Maria Zulfiati ${ }^{3}$ \\ Primary Education, Universitas Negeri Yogyakarta, Indonesia, ${ }^{1,2}$ \\ Primary School Teacher Education, Universitas Sarjanawiyata Tamansiswa, Indonesia ${ }^{3}$
}

miftakhuddin.2018@student.uny.ac.id ${ }^{1}$

First draft received: 30 May 2019 Date Accepted: 9 Jul 2019 Final proof received: 29 Aug 2019

\begin{tabular}{|l} 
Abstract \\
This quantitative study was conducted to identify the misconception between social studies and social \\
sciences among pre-service elementary teachers. Data were collected from 122 respondents drawn by \\
cluster sampling in Yogyakarta. Aiken's validity and Cronbach Alpha were then employed to examine the \\
instrument's quality. Collected data were analyzed using descriptive techniques to examine the level of \\
misconception. The popular misconceptions between social studies and social sciences were identified \\
through the criteria developed by Abraham, Grzybowski, Renner, \& Marek (1992). The results of the study \\
show that there was a greater understanding of social studies and social sciences for the specific fields of \\
geography, anthropology, and politics. The fields that were misconceived included economics, geography, \\
and history. Therefore, the main emphasis should be placed on these fields. The implications of this research \\
will eventually become the basis and guideline for social studies lecturers to give emphases on the fields of \\
study belonging to social studies,helping students distinguish these disciplines from those of social sciences. \\
In addition, each social science discipline adopted into social studies must receive special attention, given \\
the greater level of misconception among the pre-service teachers in these fields. \\
Keywords: Misconception; pre-service elementary teacher; social scicences; sosial studies \\
\hline To cite this paper (in APA style): \\
Miftakhuddin, Mustadi, A., \& Zulfiati, H. M. (2019). Misconceptions between social studies and social \\
sciences among pre-service elementary teachers. International Journal of Education, 12(1),16-25. doi: \\
10.17509/ije.v12i1.17514
\end{tabular}

\section{INTRODUCTION}

There are three qualifications for primary school teacher education program graduates, namely: teacher, educational researcher, and educational consultant (AD-PGSD, 2015). Researcher and consultant qualifications are more targeted for graduates of postgraduate education. Hence, the undergraduate primary school teacher education program is more oriented towards preparing primary school teachers. It is more specifically designed in three phases: theoretical courses, peer teaching, and real practice, as the culmination point for shaping their teaching performance (Sulthon \& Tasnim, 2012). As a pre-service teacher program, the primary school teacher education program also bears the responsibility for teaching national character building. This is so because educators should not only transfer knowledge but also value to their students (Gufron, Budiningsih, \& Hidayati, 2017). Accordingly, the emphasis in preparing pre-service teachers should lie in the field of study that lead pupils to be ideal citizens, that is social studies (NCSS, 1984; Seefeldt, Castle, \& Falconer, 2014), together with civic and religious education.

Social studies is a form of psychologically and pedagogically selective simplification of the social sciences for educational purposes (Jarolimek, 1986; NCSS, 2008); therefore, it has its own teaching techniques. Different from social science which aims to create social science experts, social studies aims to produce a society that is not just intellectually intelligent but also socially wise, a society that values equity and tolerance from different perspectives (Barton \& James, 2010; Parker, 2010; Tannebaum, 2018). Consequently, social studies should be taught starting from the paradigm of an integrated knowledge system (Hartoonian, 2010). 
To further distinguish social science from social studies, the former explains why and how a phenomenon occurs, while the latter expounds how humans should respond to the phenomenon. Therefore, social studies should be contextual, based on the spatial, temporal, and cultural aspects of the local community (Rodgers, 2011; Sukmadinata \& Alexon, 2012). This discipline is strongly associated with teachers' responsibility for conveying the values promoted by the community as hidden curricula (Kohlberg \& Hersh, 1977; Oliva, 2009). Especially for elementary school, social studies should be as practical as possible (Moedjanto, 2003). For the cognitive development of elementary school students, according to Piaget's theory, is still in the concrete operational stage, in which they can only accept lessons when the content can be observed and experienced by them (Ormrod, 2012).

Thus, social studies can be said to be essentially balancing the condition of society for the misuse of social sciences (de-axiology). Seefeldt et al. (2014) exemplify this case by showing a fragile balance between socialization and social criticism. They suggest how we want a law-abiding community, but we do not want the community to be intimidated by law or by law enforcement. We want people to support elections, but we do not want people to participate in demagogical leadership.

When a teacher misinterprets the concept of social studies or misconceives the concepts between social studies and social sciences, students will use the information they get from this discipline in an inappropriate way, or even cannot use the information at all (Keles, Erta, Uzun, \& Cans, 2010). Thus, it is imperative for pre-service teachers to have a good command of social studies (Sunal \& Haas, 2011).

However, the results of a preliminary study in a primary school teacher education program show that pre-service teachers did not completely understand the differences between social studies and social sciences. The pre-service teachers, for instance, understood geography as an important subject in order to give elementary school pupils a clear understanding on the structure of earth and solar system. Meanwhile, the aim of geography is to teach children to understand the role of humans in their environment. They also misconceived history as a subject mainly to give children a clear understanding of the past events, whereas history must actually contain didactic values (Setianto, 2012). These misconceptions mean that the pre-service teachers understood social studies in the framework of social sciences. In other words, the pre-service teachers considered social studies for elementary school a subject that should be taught academically and partially, instead of aesthetically and holistically. As Sukmadinata \& Alexon (2012) stated, the concept of social studies is close to the environment, but current practices at elementary schools tend to be partial.

Based on the finding of the preliminary study, it is necessary to conduct research into the misconceptions between social studies and social sciences among pre-service elementary school teachers, to detect conceptual errors and rectify them. The identified misconceptions can be made a basis for strengthening the conceptual understanding in reconstructing the knowledge (Çelikler \& Aksan, 2014). Therefore, the results of this study will inform and provide the basis of considerations and recommendations for educational universities regarding which disciplines require further emphasis and the kinds of lecture materials and teaching methods aligned with learning achievement targets based on scientific shreds of evidence.

There have been a number of studies on the topics of misconception of social studies. However, they have a different focus and were conducted in different regional contexts. Consequently, they could not provide solutions to social studies pedagogical issues in Indonesia. Keçe (2014), for example, trough his research about difficulties in teaching social studies, confirmed that pupils' incomplete understanding of social studies is caused by a lack of facilities, textbook-centered teaching methods, and no guidelines for teaching. Research by Ersoy (2010) revealed that teachers' failure in understanding social studies is because they do not internalize social facts as a basis for knowledge construction during their college years. Similarly, Sim, Chua, \& Krishnasamy (2017), found that social studies teachers are unable to integrate political science into social studies learning settings. Meanwhile, Segal's (1990) research findings highlight students' perception of social sciences as a purely partial subject.

None of the research revealed in detail the misconceptions between social studies and social sciences. Therefore, the present study would contribute to the existing research by focusing on the misconceptions between social studies and social sciences among pre-service elementary school teachers. The findings of this research will be the basis for enhancement in the teaching of Social Studies Basic Concept course at primary school teacher education programs, and important considerations in determining the prerequisite knowledge or courses for students who want to take advanced social studies courses

\section{METHOD}

This study used a quantitative approach and a survey design. As Creswell (2012) explained, survey design in educational research is a quantitative procedure which seeks to describe trends in pre-service teachers' thinking. Data were collected using 19 semiclosed-ended questions given to respondents $(n=122)$ chosen by cluster sampling in Yogyakarta.

Respondents in this study were 6th-semester students (consisting of 78 female and 44 male) who came from four educational universities in Yogyakarta (three private universities, and one state university). The sample was drawn from educational universities 
due to their specific curriculum of pre-service education.

The questionnaire was developed by referring to social studies and social sciences indicators formulated by experts and the National Council for the Social Studies (Beal \& Bolick, 2013; Douglass, 1967; Ellis, 1998; NCSS, 1989, 2010). The items in the questionnaire were made by referring to teacher and student handbooks of Curriculum $2013 \quad$ (2017 revision). The questionnaire was validated using Aiken's (1985) validity index, while the reliability was examined using Cronbach's Alpa.

The collected data were analyzed with descriptive statistics to examine the level of misunderstanding. The concepts exchanged between social studies and social sciences were identified by criteria developed by Abraham, Grzybowski, Renner, \& Marek (1992) which are listed and defined in Table 1.

Table 1 Scoring guideline for misunderstanding

\begin{tabular}{|c|c|}
\hline Degree of understanding & Criteria for scoring \\
\hline No response & $\begin{array}{l}\text { Blank } \\
\text { I don't know } \\
\text { I don't understand }\end{array}$ \\
\hline No understanding & $\begin{array}{l}\text { Repeats question } \\
\text { Irrelevant or unclear } \\
\text { response }\end{array}$ \\
\hline Specific misconception & $\begin{array}{l}\text { A response that include } \\
\text { illogical or incorrect } \\
\text { information }\end{array}$ \\
\hline $\begin{array}{l}\text { Partial understanding with } \\
\text { the specific } \\
\text { misconception }\end{array}$ & $\begin{array}{l}\text { Responses that show } \\
\text { understanding of the } \\
\text { concept, but also make } \\
\text { statements which } \\
\text { demonstrate a } \\
\text { misunderstanding }\end{array}$ \\
\hline Partial misunderstanding & $\begin{array}{l}\text { Responses that include at } \\
\text { least one of the components } \\
\text { of the validated response, } \\
\text { but not all the components }\end{array}$ \\
\hline Sound understanding & $\begin{array}{l}\text { Responses that include all } \\
\text { components of the validated } \\
\text { response }\end{array}$ \\
\hline
\end{tabular}

The measurement standard of those criteria refers to a dichotomy between social studies and social sciences as put forward by experts and the National Council for the Social Studies (Beal \& Bolick, 2013; Douglass, 1967; Ellis, 1998; NCSS, 1989, 2010).

\section{RESULTS AND DISCUSSION}

Historians work with historical methods, geographers work with regional methods, but social studies teachers work with pedagogical methods. That is why pre-service teachers need to fully understand "what will be taught" and find out "how to teach" it. Therefore, the principal misconceptions in the field of social studies for pre-service teachers must be rectified. The results of this study indicate that the pre-service teachers' understandings of social studies and social sciences generally overlapped and confused with each other. Guided by research questions and data analysis technique, the results of this study will be explained into two following sections.

\section{Results}

The pre-service teachers generally lacked fundamental comprehension of social studies and social sciences. The misconceptions between social studies and social sciences in this study were rooted in the pre-service teachers' psychological understanding of social studies as a singular subject that has specific purposes. This primary misconception triggered a tendency in the orientation of their understanding, such as their confusion of the educational goals of social studies diverted by the those of social sciences.

For the first subject, economics, $37.70 \%$ of the pre-service teachers understood it as a sub-subject in social studies whose aim is for pupils to know the economic system in the society, as well as profit-loss in business, so that they will be motivated to be an entrepreneur. This misunderstanding is included in the specific misconception category because their understanding is based on wrong reasoning. Although economics often talks about money, its main purpose in elementary school is to introduce children to market mechanisms and the pattern of relationships between sellers and buyers in the process of production, distribution, and consumption. Unfortunately, only $1.64 \%$ of the pre-service teachers reached this level of understanding (sound understanding category). Most of them $(34.43 \%)$ had a partial understanding, assuming that economics in social studies was to teach pupils how to determine priorities in their lives, such as: separating between wants and needs, financial management, and savings. The rest $(4.10 \%)$ were included in the partial understanding with specific misconception category. The pre-service teachers in this category considered economics necessary to be taught because pupils needed to know about all economic activities and how the activities affect them. That means that the pre-service teachers' understanding was more inclined towards social sciences, not social studies. This result is very different from their understanding of sociology.

For sociology, $45.08 \%$ of the pre-service teachers had a sound understanding. Sociology in social studies is to sensitize the pupils as individuals, as part of the social system, and to make them obey social institutions through norms and customs. $31.15 \%$ of the pre-service teachers were included into partial understanding category, considering the need for sociology in social studies for elementary school as limited to equipping pupils to be able to properly socialize by studying people's lifestyle. Only $4.10 \%$ and $3.28 \%$ of the pre-service teachers were in the category of specific misconception (learning sociology to increase knowledge about sociology), and partial understanding with specific misconception (learning sociology to understand the culture and developing 
personality for socializing). This result indicates that the cognitive ability of the pre-service teachers in separating sociology into the dichotomy of social studies and social sciences was better than their ability in economics, in which $27.70 \%$ of pre-service partial understanding, assuming the instructional objective of anthropology was to introduce various cultures and how they interact according to prevailing habits. The rest $20.49 \%$ were included in the category of partial understanding with specific misconception.

Table 2. Degree of Bias at Social Studies and Social Sciences

\begin{tabular}{lccccccccc}
\hline \multirow{2}{*}{ Degree of Understanding } & \multicolumn{3}{c}{ SOCIAL STUDIES \& SOCIAL SCIENCES (\%) } & \multirow{2}{*}{ STDEV } & \multirow{2}{*}{ mean } \\
\cline { 2 - 7 } & Eco & Soc & Geo & His & Ant & \multicolumn{2}{c}{ Pol } & & \\
\hline Specific misconception & 37.70 & 4.10 & 24.59 & 44.26 & 0.00 & 9.84 & 18.33 & 20.08 \\
\hline Partial understanding with specific misconception & 4.10 & 3.28 & 17.21 & 0.82 & 20.49 & 21.31 & 9.44 & 11.20 \\
\hline Partial understanding & 34.43 & 31.15 & 16.39 & 36.07 & 9.84 & 18.85 & 10.85 & 24.45 \\
\hline Sound understanding & 1.64 & 45.08 & 21.31 & 0.00 & 12.30 & 14.75 & 16.44 & 15.85 \\
\hline
\end{tabular}

teachers had specific misconception. However, this understanding of sociology is almost inversely proportional to the understanding of history.

For history, $44.26 \%$ of the pre-service teachers were included in the specific misconception category. More precisely, 54 students thought that children should study history so they will know about the past events objectively. Some even thought that children should study history so that they will know about their origin. Meanwhile, only $0.82 \%$ of them had partial understanding with specific misconception, assuming children learning history in order to be able to compare past and present situations. Essentially, history as a science is aimed to reveal the truth by examining the facts of the past, but as an elementary school subject history is intended to shape a nationalist and patriotic personality (understood by $22.13 \%$ of the pre-service teachers) and evaluate past events to take any lessons from them (understood by $13.95 \%$ of them). None of the students achieved sound understanding level, characterized by the ability to mention all the goals of historical learning. In fact, to take lessons from the past, $31.15 \%$ of the pre-service teachers believed that pupils should learn from myths and legends instead.

The greatest misconception was for anthropology, in which $38.52 \%$ of the pre-service teachers were included in no understanding category. Anthropology in social studies, for them, aimed to promote ethnocentrism by studying ancestral identity. Actually, the main purpose of anthropology is to make children mindful that as part of the society they should be civilized. Culture is no longer something close to the children but inherently integrated into their daily lives. Therefore, through the content of anthropology, children shall learn the patterns of human behaviors that build and develop a civilization as a result of human thoughts. Children will support the formation of civil society by utilizing cultural products in human life. This sound understanding of anthropology was only demonstrated by $12.30 \%$ of the pre-service teachers. Unfortunately, most pre-service teachers did not have such understanding, where $9.84 \%$ of them only had
This understanding was demonstrated by the assumption that elementary school pupils need to learn culture in order to know the evolution of culture and respect others' identities.

In contrast to misconceptions about anthropology, in politics the misconceptions appeared to be overlapping with other subjects. Although $14.75 \%$ of the pre-service teachers understood the importance of politics for elementary school pupils to support and strengthen democracy, deliberation principles, and good citizens, $21.31 \%$ of them belonged to the category of partial understanding with specific misconception. They assumed that politics in terms of social studies was important so that children would be politically literate. As stated by respondent ST37: "knowledge of politic needs to be conveyed to elementary pupils because they will be asked to vote." Meanwhile, pre-service teachers who had partial understanding (18.85\%) considered politics for elementary school pupils to serve the function of explaining the division of tasks and introducing their rights and obligations. The results of this study confirm that the misconception or bias between politics as social science and politics as part of social studies lies in the problematic understanding between "practical politics" and "essential politics". More than $30 \%$ of the pre-service teachers argued that politics in social studies for elementary school was practical politics, whereas it should be understood as essential politics. This failure to distinguish educational interest was also observed in the understanding of geography.

The pre-service teachers' understanding of geography was more oriented to cognitive mastery of the solar system, soil and rock structure, and spatial scheme. This specific misconception was demonstrated by at least $24.50 \%$ of them, whereas $17.21 \%$ of the pre-service teachers had a partial understanding with specific misconception. For them, geography should to be taught so that pupils could learn about map and national boundaries. This understanding is, of course, not entirely wrong. It is just incomplete because it does not show the urgency of geography for elementary school pupils. Geography 
in social studies should educate the pupils about appearances of natural environment, encouraging them to relate the natural environment to human behaviors, such as a culture of society, livelihoods in specific environmental characteristics (topography), and to behave wisely in their surroundings. This is the sound understanding of geography, which was only achieved by $21.31 \%$ of the pre-service teachers. The rest $(16.39 \%)$ were included in partial understanding category, considering geography necessary so that children would know their surrounding neighborhood. With a ratio of $24.59 \%$ to $21.31 \%$, it can be said that the existing misconceptions in geography were caused by the pre-service teachers' understanding of this subject as part of social sciences rather than as an integrated part of social studies. One of the clearest pieces of evidence is the pre-service teachers' understanding of the purpose of geography as being less associated with children's world.

\section{Discussion}

In the research of Baysal, Arkan, and Bagci (2011), pre-service elementary school teachers believe that social studies learning is effective to train problemsolving and decision-making abilities. However, the misconceptions revealed in this study create a doubt in the abilities of the pre-service teachers to deliver what they believe in the real classroom settings. Because of misconceptions, one of Comber's (2006) five teacher's works cannot be fulfilled, namely pedagogical work, which is related to teacher's knowledge about material content and the way to convey it. This study indicates that pre-service teachers have some misconceptions, in the form of misunderstandings about the objectives of social sciences' adoption into social studies. in addition to misconceptions, to a certain extent, the pre-service teachers demonstrated overlapping understanding of the concepts. This conclusion is obtained based on data analysis, indicating that the understandings of most pre-service teachers were included in the categories of specific misconception and partial understanding with specific misconception.

The three social science disciplines with the greatest specific misconceptions were economics $(37.70 \%)$, history $(44.26 \%)$, and geography $(24.59 \%)$. Misconception at this level is relatively convenient to overcome because its indicators are clear. This is different from partial understanding with specific misconceptions that is more difficult to overcome because the pre-service teachers showed correct understandings and misconceptions at the same time. This kind of misconception was more common in geography $(17.21 \%)$, anthropology $(20.49 \%)$, and politics (21.31\%).

In economics, $37.70 \%$ of the pre-service teachers fell into the specific misconception category. This figure is greater than the partial understanding category, which is $34.43 \%$. The result means more pre-service teachers believed economics was the knowledge required to do effective business and contains guidelines to be entrepreneurs and get the greatest possible profit by keeping expenses as low as possible. This result implies the need for special emphasis on learning the basic concepts of economics in the primary school teacher education program. If necessary, the lecture should start from the most fundamental concept to highlight that the main objective of economics in elementary school social studies is to introduce children to market mechanisms and the fulfillment of human necessity. Consequently, it is necessary to teach about bartering as the most basic buying and selling concept. Through this manner, as Farris (2015) stated, pre-service teachers will understand that their task is to make children evaluate their position, so that they can decide whether they will offer goods or services in the surrounding economic processes.

Even worse than economics misconceptions, the level of misconceptions for history reached $44.26 \%$ for specific misconception and $36.07 \%$ for partial understanding. Although Table 2 shows that most of the pre-service teachers understood history incorrectly, their understanding was almost diametrically separated between history as social science and history as social studies. According to $44.26 \%$ of the pre-service teachers, history in social studies teaches various reasons for an event, important dates, figures involved, and legacy of specific events. In fact, Setianto's (2012) research has emphasized that history as an academic subject in schools must contain educational values. It is not enough to inform children objectively about what happened in the past; rather, teachers should encourage them to reconstruct the wisdom of what can be drawn from the events. Thus, history is no longer considered an old-boring-memorizing subject, due to emphasis on exploring the didactic values of a past event (Kartodirdjo, 1992).

Compared to other social science disciplines, history teaching requires a special technique. This is mainly because teaching history is concerned with finding a path between the past, present, and future. In the elementary school context, history must not only engage pupils to imagine situations where events took place (Maclsaac, 1996), but must also heed to historical facts in the local and national scopes because social studies must be taught contextually. Furthermore, a study by Akcali \& Demircioglu (2016) revealed that the pre-service elementary teachers in their study were well-informed about the historical environment, but they had a lack of requisite skills. In this regard, Kuntowijoyo (1995) advised that history in elementary school must be taught aesthetically, so that pupils can imagine the events and take any lessons from them. In college level, history is taught academically, so that pre-service teachers are bounded by the facts. Accordingly, the appropriate approach to teach history as part of social studies to pre-service elementary teachers is to use an academic and aesthetic approach in a properly integrated or inclusive model. 
In order to avoid misconceptions about teaching history, some alternatives based on the Vygotsky's (1978) constructivist theory paradigm must be introduced to pre-service teachers. This theoretical framework is important to facilitate pre-service teachers' understanding built from their intellectual experience about the past, present, and new socially mediated knowledge (Vygotsky's Zone of Proximal Development). One alternative strategy is the "firstperson presentation" by Morris (2009), where history is taught in specific themes according to the abilities and cognitive development stage of each grade. In this way, pre-service teachers will avoid misconceptions because the method is focused on making pre-service teachers aware of their existence in the passage of time; they are the product of past events (Arnold, 2000), who live in the present, will determine the future and, in turn, will also be history.

However, this study also confirms previous research finding that the biggest challenge is not misunderstanding about history but geography. A study in the United States from 1994 to 2001 revealed a correct understanding of geography teaching was low (below 5\%) and tended to decrease (Zarrillo, 2011). Likewise, in the research of Pinar \& Akdag (2012), instead of being able to distinguish between geography as part of social studies and geography as social sciences, pre-service teachers misunderstood the beginning concepts, such as wind, climate, temperature, precipitation, and maps. Consequently, they did not understand, for instance, the relationship of climate to economic activities and cultural practices (Brophy \& Alleman, 2006). This study, then, further confirms that the misunderstanding found by Brophy \& Alleman (2006) is categorized as specific misconception, where the physical characteristics of the earth are seen as the only object of geography.

In addition to specific misconception (24.59\%), this study detected partial understanding with specific misconception (17.21\%), where the pre-service teachers understood the purpose of geography in social studies as being limited to territoriality and layout of an object. This means that pupils will spend more time doing map-reading, whereas not all pupils may be considered ready for it. This mismatch between pupils' readiness and the method will be a problem (Brophy \& Alleman, 2009). To address this problem, the great child psychologist, Jean Piaget, has investigated children's readiness in reading maps. In his discovery, children go through three phases to see things from different perspectives before they can read maps properly (Piaget \& Inhelder, 1969). The first phase is topographical stage (the child cannot determine the direction), and then $\mathrm{s} / \mathrm{he}$ will pass the projective stage ( $\mathrm{s} / \mathrm{he}$ can define the location and relate it to his/her position). The last one is the ability commonly achieved by children aged $10-12$ years, which Piaget calls Euclidean stage, where the child already has an accurate perception of spatial relationships.
Euclidean stage is the best time to introduce pupils to the environment and their relationship with it. This is because the phase occurs right after early grades of social studies which only allow for limited sociology: about child his self, family, and neighborhood (Field, Bauml, LeCompte, \& Alleman, 2009). This sequence must be understood by preservice teachers who have partial understanding with specific misconception, so that their understanding will be consistent with the nature of geography as part of social studies, namely human interactions with their environment and, as result, how both (human and place) experience the changing (Gersmehl, 2005).

In general, misconceptions about economics, history, geography, and other social studies are rarely revealed, because their rich-content characteristics make it difficult for lecturers to determine whether preservice teachers hold misconceptions or not (Hess, 2006). Karatekin's (2013) research has proven that too much and complex content often complicate students' understanding. In his research on sociology, it was found that pre-service teachers had more misunderstandings between "socialization" and "social institutions." The discovery of specific misconception $(4.10 \%)$ and partial understanding with specific misconception (3.28\%) in this study confirms Karatekin's (2013) research, and at once confirms Brophy \& Alleman's (2009) research that misconceptions are more common in rich-content subjects. Although misconceptions in social studies, as argued by Hess (2006), are difficult to detect, they can be clearly seen in overlapping concepts between social studies and social sciences. This overlap then causes misconceptions between social studies and social sciences.

One of the clearest examples is Segal's (1990) research, which reveals the causes of misconceptions between the concepts of social studies and social sciences were more dominated by academic background and the inability of pre-service teachers to grasp the material context. In other words, failure to understand academic subjects is caused by the inability to generalize meaning (Tovani, 2000). Thus, according to Macbeath (2014), such misconceptions will transform into myths and heresy in educational activity.

Vygotsky's sociocultural learning theory has clearly explained this phenomenon. Personal preferences and past experiences with others will shape one's cognitive structure. They tend to intervene with intellectual experience in shaping new knowledge (Crain, 2014; Ormrod, 2016). For example, pre-service teachers who graduate from an economic school will see the purpose of economics as the subject which teaches children to capitalize on available resources. Likewise, pre-service teachers who used to be active in school organizations will assume that politics is needed because pupils would be a political actor (to vote or be voted). In this case, pre-service teachers skip the main goal of politics content in social studies, which is to internalize 
"essential politic" so that children will become good and democratic citizens (Boyle-baise \& Zevin, 2009). Furthermore, political practices in elementary school do not go as far as general elections, even though there is class leader election. The aim of politics in elementary school is to provide more space for "essential politic" than "practical politic" (Obenchain \& Pennington, 2015). The orientation is limited to the attitude of respecting different opinions, perspectives, and everyone's rights and obligations. Thus, children will learn that everyone is equal (Wade, 2007).

Brophy \& Alleman (2009) realized that elementary school teachers are not confident in teaching politics because they believe that their pupils are not interested in the subject. It is true that pupils will not respond well to abstract theories about governance and policies. The inability to simplify this material is one of the misconception indicators. Therefore, Brophy \& Alleman (2009) suggest to develop learning based on principal ideas; people need the government to provide essentials that are too big, complicated, or expensive to provide by themselves. These needs include national security, health services, schools, transportation infrastructure, police protections from the crime, and many others. This concept helps children to understand why government is needed and what the government do for society, including tax collection which is eventually used for common good.

Indeed, rich-content social studies need to be organized and presented with a primary emphasis on preparing for life in general and shaping citizenship attitudes in particular. Especially for Indonesia as a multicultural nation, anthropology must be integrated with other social science disciplines in social studies subject. The finding of $20.49 \%$ partial understanding with specific misconception in this study indicates the magnitude of the errors in the understanding of preservice elementary teachers about anthropology. Its long-term impact, according to Barret \& BuchananBarrow (2005), is not just ethnocentrism, but also cultural chauvinism (depicting unfamiliar customs as funny, weird, odd, etc.).

This study, after all, confirms Kilinç's (2014) and Goodman \& Adler's (2012) research that pre-service elementary teachers have a different but uneven understanding of the three traditions in Social Studies: citizenship transmission, social science, and reflective inquiry (Barr, Barth, \& Shermis, 1977). In Kilinç's (2014) findings, pre-service teachers understand social studies more in terms of reflective inquiry (social studies to solve the problem). Similarly, in this study, most pre-service teachers (mean $=24.45 \%$ ) were included in partial understanding category. As for the findings of Goodman \& Adler (2012), a small percentage of pre-service teachers have misconceptions about the aims of social studies for elementary school-aged children. Some pre-service and in-service teachers assume that social studies is a non-subject and concerned with human relations, while most of them assume that social studies is school knowledge, integrative core of the elementary curriculum and education for social action. Likewise, in this study, it was found that only $11.20 \%$ of pre-service teachers belonged to the category of partial understanding with specific misconception.

However, on the other hand, this study disconfirms the research results of Hawe, Browne, Siteine, \& Tuck (2010), who found that pre-service elementary teachers stood in a neutral position in facilitating pupils' knowledge about social studies. This means there are neither misunderstanding nor trends in any scope (social studies and social sciences). Thus, pre-service teachers should master the concepts of their subjects adequately, supported by the ability to select appropriate sources and teaching strategies (Maxim, 1987). One of the most recommended solutions is the use of controversial issues in the closest social environment of pupils as a source and main learning materials (Maynes \& Straub, 2012).

\section{CONCLUSIONS}

Most of the misconceptions were in the partial understanding category (mean $=24.45 \%$ ). That is to say, the pre-service teachers were closer to the right understanding than the wrong one. The overlapping understanding can then be concluded to be more inclined to good understanding $(24.45 \%$ for partial understanding, and $15.85 \%$ for sound understanding). On the other hand, specific misconception was only at the level of $20.08 \%$ and partial understanding with specific misconception $11.20 \%$. The rest $22.81 \%$ and $5.60 \%$ belonged to the no understanding category and no response category, respectively. These last two categories cannot be analyzed since they did not show any misconceptions of the pre-service teachers between social studies and social sciences.

This study revealed that the disciplines that caused the most misconceptions were economics (37.70\%), geography (24.59\%), and history (44.26\%). However, the hardest tasks lie in rectifying the misconceptions of geography, anthropology, and politics. This is because the three disciplines had the greatest frequency in partial understanding with specific misconception category. This percentage underscores the need for an emphasis on those disciplines in the course of Basic Social Studies offered in elementary school teacher education program. Politics and sociology also need to be reinforced, but not as urgent as anthropology because the misconceptions only scored $4.10 \%$ and $9.84 \%$, respectively. The treatment for anthropology misconceptions should refer to ideas about multiculturalism and cultural diversity, particularly due to the $20.49 \%$ of pre-service teachers with partial understanding with specific misconception. This concept is necessary to prevent pupils and pre-service teachers from ethnocentrism and chauvinism.

As the nature of survey design, this study reveals what, who, how much, and at what level the misconceptions were. This study cannot explain why 
and how misconceptions occur. This is the limitation of this study that hopefully can be addressed by future research.

\section{Acknowledgment}

We express our gratitude to Dr. Anwar Senen for his guidance in the Social Studies course that has motivated us to conduct a study on the misconceptions between social studies and social sciences among pre-service elementary school teachers in educational universities.

\section{REFERENCES}

Abraham, M. R., Grzybowski, E. B., Renner, J. W., \& Marek, E. A. (1992). Understandings and misunderstandings of eighth graders of five chemistry concepts found in textbooks. Journal of Research in Science Teaching, 29(2), 105120. https://doi.org/10.1002/tea.3660290203

AD-PGSD. (2015). Capaian pembelajaran: program pendidikan guru sekolah dasar, program pendidikan profesi guru SD, program magister pendidikan dasar, program doktor pendidikan dasar. Asosiasi Dosen PGSD Indonesia.

Aiken, L. R. (1985). Three coefficients for analyzing the reliability and validity of ratings. Educational and Psychological Measurement, 45, 131-142.

Akcali, A. A., \& Demircioglu, I. H. (2016). Opinions of pre-service social studies teachers about using historical environment. International Electronic Journal of Elementary Education, 9(1), 39-58.

Arnold, J. H. (2000). History: A very short introduction. Oxford: Oxford University Press. https://doi.org/10.1093/actrade/9780192853523. 001.0001

Barr, R. D., Barth, J. L., \& Shermis, S. A. (1977). Defining the social studies. Silver Spring: National Council for the Social Studies.

Barret, M., \& Buchanan-Barrow, E. (2005). Children's understanding of society. New York: Psychology Press.

Barton, K. C., \& James, J. H. (2010). Religion in history and social studies. Perspectives: Newsmagazine of the American Historical Association, 48(5), 50-51.

Baysal, Z. N., Arkan, K., \& Bagci, M. S. (2011). Elementary school teacher candidates' opinions on the social studies program regarding its suitability to train problem solving and decision making abilities. Elementary Education Online, 10(2), 539-549.

Beal, C., \& Bolick, C. M. (2013). Teaching social studies in middle and secondary schools (6th ed.). Boston: Pearson Education.

Boyle-baise, M., \& Zevin, J. (2009). Young citizens of the world: Teaching elementary social studies through civic engagement. New York: Routledge.

Brophy, J., \& Alleman, J. (2006). Children's thinking about cultural universals. Mahwah, NJ: Erlbaum.

Brophy, J., \& Alleman, J. (2009). Meaningful social studies for elementary students. Teacher and Teaching: Theory and Practice, 15(3), 357-376. https://doi.org/10.1080/13540600903056700

Çelikler, D., \& Aksan, Z. (2014). Determination of knowledge and misconceptions of pre-service elementary science teachers about the greenhouse effect by drawing. Procedia - Social and Behavioral Sciences, 136, 452-456. https://doi.org/10.1016/j.sbspro.2014.05.355

Comber, B. (2006). Pedagogy as work: Educating the next generation of literacy teachers. Pedagogies: An International Journal, 1(1), 5967. https://doi.org/10.1207/s15544818ped0101 9

Crain, W. (2014). Theories of development: Concepts and applications (6th ed.). Edinburgh: Pearson Education.

Creswell, J. W. (2012). Educational research: Planning, conducting, and evaluating quantitative and qualitative research. Educational Research (4th ed., Vol. 4). New Jersey: Pearson Education. https://doi.org/10.1017/CBO9781107415324.004

Douglass, M. P. (1967). Social studies: From theory to practice in elementary education. New York: Lippincott Company.

Ellis, A. K. (1998). Teaching and learning elementary social studies (6th ed.). Needham Heights: Allyn and Bacon.

Ersoy, A. F. (2010). Social studies teacher candidates' views on the controversial issues incorporated into their courses in Turkey. Teaching and Teacher Education, 26(2), 323-334. https://doi.org/10.1016/j.tate.2009.09.015

Farris, P. J. (2015). Elementary and middle school social studies (7th ed.). Long Grove, Illinois: Waveland Press.

Field, S. L., Bauml, M., LeCompte, K., \& Alleman, J. (2009). Mexico, our closest neighbor: Three elementary teachers' perspectives. The Social Studies, 100(6), 37-41. https://doi.org/10.1080/00377990903340385

Gersmehl, P. (2005). Teaching geography. New York: Guilford Press.

Goodman, J., \& Adler, S. (2012). Becoming an elementary social studies teacher: A study of perspectives. Theory \& Research in Social Education, 13(2), 37-41. https://doi.org/10.1080/00933104.1985.1050549 6

Gufron, A., Budiningsih, C. A., \& Hidayati. (2017). Developing instructional model based on cultural values of yogyakarta at primary school. Cakrawala Pendidikan, 37(2), 309-319.

Hartoonian, H. M. (2010). The social studies and project 2061: An opportunity for harmony. The Social Studies, 83(4), 160-163. https://doi.org/10.1080/00377996.1992.9956224

Hawe, E. M., Browne, I., Siteine, A., \& Tuck, B. (2010). Beliefs of experienced and student teachers about the nature and purpose of social studies 
education in New Zealand elementary schools. Asia Pacific Journal of Education, 30(3), 37-41. https://doi.org/10.1080/02188791.2010.495842

Hess, D. E. (2006). Identifying and teaching against misconceptions: Six common mistakes about the supreme court. Social Educ, 70(6), 337-342.

Jarolimek, J. (1986). Social studies in elementary education (7th ed.). New York: The Macmillan Company.

Karatekin, K. (2013). Social studies student teachers' levels of understanding sociology concepts within social studies curriculum. Educational Research and Review, 8(4), 144-153.

Kartodirdjo, S. (1992). Pendekatan ilmu sosial dalam metodologi sejarah. Jakarta: Gramedia Pustaka Utama.

Keçe, M. (2014). Problems related to the teaching of social studies and suggestions for solution: Teachers' opinion based on a qualitative research. Procedia - Social and Behavioral Sciences, 122, 388-392. https://doi.org/10.1016/j.sbspro.2014.01.1359

Keles, Ö., Erta, H., Uzun, N., \& Cans, M. (2010). The understanding levels of preservice teachers ' of basic science concepts' measurement units and devices, their misconceptions and its causes. Procedia - Social and Behavioral Sciences, 9, 390-394.

https://doi.org/10.1016/j.sbspro.2010.12.170

Kilinç, E. (2014). Pre-service social studies teachers' understandings about the nature of the social studies. International Electronic Journal of Elementary Education, 6(3), 415-426.

Kohlberg, L., \& Hersh, R. H. (1977). Moral development: A review of the theory. Theory into Practice, 16(2), 53-59. https://doi.org/10.2307/1475172

Kuntowijoyo. (1995). Pengantar ilmu sejarah. Yogyakarta: Yayasan Bentang Budaya.

Macbeath, J. (2014). Education and schooling: Myth, heresy and misconception. Third Avenue, NY: Routledge.

Maclsaac, T. (1996). From Collingwood Teaching. Teaching History, 84, 15-18.

Maxim, G. W. (1987). Social studies and the elementary school child. Columbus: Merrill Publishing.

Maynes, N., \& Straub, J. (2012). Social studies: Innovative Approaches for Teachers. Toronto: Pearson.

Moedjanto, G. (2003). Social sciences dan social studies. Retrieved March 5, 2019, from perpustakaan.bappenas.go.id

Morris, R. V. (2009). Bringing history to life: Firstperson historical presentations in elementary and middle school classroom. Toronto: Rowman \& Littlefield Education.

NCSS. (1984). Task force on scope and sequence: In search of a scope and sequence for social studies. Washington DC: National Council for the Social Studies.
NCSS. (1989). In search of a scope and sequence for social studies: Report fo the national council of the social studies task force on scope and sequence. Washington DC: National Council for the Social Studies.

NCSS. (2008). A vision of powerful teaching and learning in the social studies: Building social understanding and civic efficacy. A position statement. Washington DC: National Council for the Social Studies.

NCSS. (2010). National curriculum standards for social studies : Executive summary. Washington DC: National Council for the Social Studies.

Obenchain, K. M., \& Pennington, J. L. (2015). Educating for critical democratic literacy: Integrating social studies and literacy in the elementary classroom. New York: Routledge.

Oliva, P. F. (2009). Developing the curriculum (7th ed.). Boston: Pearson Education.

Ormrod, J. E. (2012). Human Learning (6th ed.). New Jersey: Pearson Education.

Ormrod, J. E. (2016). Human learning (7th ed.). Boston: Pearson Education.

Parker, W. C. (2010). Social studies today: research and practice. New York: Routledge.

Piaget, J., \& Inhelder, B. (1969). The psychology of the child (Translated by $\mathrm{H}$. Weaver). New York: Basic Books.

Pinar, A., \& Akdag, H. (2012). Social studies teacher trainees' comprehension level of climate, wind, temperature, precipitation, erosion, ecology, and map concepts. Elementary Education Online, 11(2), 530-542.

Rodgers, A. (2011). Redesign and professionalizing teacher education by piloting alternatives to traditional supervision: Addressing the challenges of the Indonesian context. International Journal of Education, 5(2), 121133. https://doi.org/10.17509/ije.v5i2.5277

Seefeldt, C., Castle, S., \& Falconer, R. C. (2014). Social studies for the preschool/primary child (9th ed.). Boston: Pearson Education.

Segal, R. A. (1990). Misconceptions of the social sciences. Zygon, 25(3), 263-278.

Setianto, Y. (2012). The dicotomy between value-free and educational value in history learning. Jurnal Pendidikan Dan Kebudayaan, 18(4), 477-488.

Sim, J. B., Chua, S., \& Krishnasamy, M. (2017). "Riding the citizenship wagon": Citizenship conceptions of social studies teachers in Singapore. Teaching and Teacher Education, 63 , https://doi.org/10.1016/j.tate.2016.12.002

Sukmadinata, N. S., \& Alexon. (2012). The development of culture-based integrated learning model to improve students' appreciation on local culture. International Journal of Education, 6(2), 129-142. https://doi.org/10.17509/ije.v6i2.5298

Sulthon, M., \& Tasnim, Z. (2012). Quality improvement fo PPL output for PGSD students through a 
Lesson Study guided by clinical supervision. Jurnal IImu Pendidikan Sekolah Dasar, 1(2), 234-245.

Sunal, C. S., \& Haas, M. E. (2011). Social studies for the elementary middle grades: A constructivist approach (4th ed.). Boston: Pearson Education.

Tannebaum, R. p. (2018). Teaching about religion within early chilhood and elementary social studies: Exploring how preservice teachers perceive their rights and responsilities as educators. Journal for Social Studies Education Research, 9(4), 30-48.

Tovani, C. (2000). I read it, but I don't get it: Comprehension strategies for adolescent readers. Portland: Stenhouse Publishers.

Vygotsky, L. S. (1978). Mind in society: The developmental of higher psychological processes. Cambridge: Harvard University Press.

Wade, R. C. (2007). Social studies for justice: Teaching strategies for the elementary classroom. New York: Teachers College Press.

Zarrillo, J. J. (2011). Teaching elementary social studies: Principles and applications (4th ed.). Boston: Pearson Education. 